\title{
Solar parameters of the local climate during the summer in relation to data from typical meteorological year
}

\author{
Joanna Rudniak ${ }^{1, *}$ \\ ${ }^{1}$ Czestochowa University of Technology, Faculty of Infrastructure and Environment, \\ ul. Brzeźnicka 60a, 42-200 Częstochowa, Poland
}

\begin{abstract}
Parameters characterizing the properties of the local climate, among them the solar irradiance, as part of the so-called Typical Meteorological Year-TMY, are often averaged and modeled. To determine the actually available solar conditions, it is beneficial to perform additional studies of climate factors in specific locations. The article presents the analysis of the solar irradiance measurements results for Częstochowa, carried out in June, July and August, in different years, in comparison to data from typical meteorological year for this period. TMY developed in Poland as well as TMY from PVGIS databases were used. Due to the occurrence of significant discrepancies in the values of solar irradiance, in the considered large data sets, it was found necessity to update the currently used TMY PL for Częstochowa, which were determined on the basis of data from the years 1971-1991. The analysis also included local sunshine duration and its summer anomalies. In addition, the dependence of solar conditions on the particulate matter $\mathrm{PM}_{10}$ content in the air, which is rarely considered in the summer, is presented.
\end{abstract}

\section{Introduction}

In the dispersed energy sector, the share of energy obtained from renewable energy sources is increased more and more often, by supplying electricity and heat, thanks to the use of, for example, solar collectors or photovoltaic cells [1-5]. However, the effective operation of solar installations in specific locations is largely influenced by the availability of solar energy resources, which undoubtedly depend on the time of day or season of the year [5, 6]. These resources depend also on the specific features of the local climate, share of different types of air masses, air transparency, humidity and chemical composition of air, cloudiness, etc. [7-9]. A typical data set from the meteorological year TMY provides a database of values for various climate parameters, often used by designers to determine energy demand for heating and cooling, in engineering calculations of simulated energy performance of buildings, as well as in the modeling of renewable energy conversion systems, especially solar energy $[1,5,10,11]$. In the absence of standard actinometrical measurements in many small meteorological stations [12] the values of solar irradiance included in TMY are

\footnotetext{
*Corresponding author: joa@is.pcz.czest.pl
} 
modeled and, unfortunately, differ significantly from the actual local conditions [13, 14]. Often, the sets of parameters that form the basis for determining TMY do not take into account the currently occurring climate changes and the evolving of weather factors $[6,10$, $11,15]$. Meteorological conditions describing the local, average climate, as typical for a given region, have been developed for many geographical areas [16, 17].The World Meteorological Organization (WMO) has recommended that each member country update their climate normals every 10 years.[18]. The analysis of the long-term radiation data from many places in European countries confirms over 10-year oscillations of the researched global solar radiation courses [19-21]. For Polish cities, they were designated on the basis of many years of research on weather conditions conducted by Institute of Meteorology and Water Management - National Research Institute IMGW-PIB [22]. For the determination of TMY, measurements of local meteorological parameters were performed hourly, including also the solar irradiance. Data describing solar conditions are given additionally for the directions of the world and inclination angles [22]. The period of record of meteorological measurements, used for TMY, is usually 30 years $[10,11,23]$ and short-term fluctuations and data anomalies are filtered.

In order to determine the scale of variability of factors, from such a large amount of data, the most representative months, twelve Typical Meteorological Months TMM, are most often selected, with average values closest to the monthly average over the entire measurement period [10, 13, 14]. Combined months, essentially without modification, form a representative Typical Meteorological Year TMY, containing 8760 hourly meteorological values that characterize the conditions in a given place. The resulting TMY set contains measured and modeled data, because in the absence of original observations, the data are interpolated. TMY does not contain information about extreme meteorological conditions, but represents typical conditions [10, 11]. There are different types of Typical Meteorological Years in the world [10, 11, 22-28]. Some sets also represent a year with a warmer summer than typical and contain files of extreme weather conditions in the summer.

Examples are, among others [10, 11, 22-28]: • Typical Meteorological Year - TMY or TMY2 • Test Reference Year - TRY • Design Reference Year - DRY • Weather Year for Energy Calculations - WYEC or WYEC2 - Typical Meteorological Year according to EN ISO 15927-4 • International Weather for Energy Calculations - IWEC. And additionally, for the summer period: • Design Summer Year - DSY • Near-extreme Summer Reference Year - SRY • Extreme Meteorological Year - XMY • Probabilistic Design Summer Year-PDSY.

\section{Measurements and data sources}

Częstochowa is a city located in the south of Poland, in the northern part of the Silesia Voivodeship, in the temperate climate zone. The values of solar irradiance obtained from measurements carried out in Częstochowa, at the exact location 50 49'49.5"N 1907'26.8"E (Institute of Environmental Engineering), were used to analyse the summer local solar conditions. Observations of solar conditions were conducted for the three summer months: June, July, August, from the $3^{\text {rd }}$ of June till the $31^{\text {st }}$ of August, which gives 90 calculation days respectively. The obtained data provided information on the amount of solar irradiance reaching the sensor at a given moment, and were expressed in $\mathrm{W} / \mathrm{m}^{2}$ [29]. For current main measurements in 2018, the Vantage Pro2 Plus version was used. The values of various weather factors, such as: solar irradiance, temperature, air humidity, precipitation, wind speed and direction, etc., were collected by an Integrated Sensor Suite ISS, and then sent via the interface module to the console by cable connection. The obtained material was collected in an electronic version. The measurement range of the used pyranometer for solar irradiance 
was $0-1800 \mathrm{~W} / \mathrm{m}^{2}$. Current local measurements were carried out with a time resolution of 10 minutes, as a result of which a set of 12540 values of solar irradiance were received. Archival auxiliary measurements of the summer solar irradiance, used for comparison, were carried out in the same location, in 2006, using the S-LIB-M003, the Solar Radiation Smart Sensor, silicon pyranometer, integrated with the HOBO Micro Station Data Logger H21-001 recorder, and then collected in an electronic version. The measurement range of the used pyranometer for solar irradiance was $0-1280 \mathrm{~W} / \mathrm{m}^{2}$. Archival measurements of solar irradiance were carried out with a much higher time resolution -1 minute, hence the base included a very extensive collection of 126900 values. The daylength in the selected summer period has been averaged up to 16 hours from 24 hours a day, according to [30]. This made it possible to reject, from the zero data sets, the values of the solar irradiance generated automatically for 8 hours of the night. Obtained from the measurements carried out, the sets of solar irradiance values were compared with the selected part of a Typical Meteorological Year TMY representing the summer period. Data for Częstochowa were gained from two currently available sources containing averaged databases with a time resolution of 1 hour:

- Typical Meteorological Year (TMY PL), provided by Ministry of Investment and Development [31], which was created from the study of climatic factors measured by the IMGW-PIB [22], for 61 locations in Poland, in the years 1971-2000. For Częstochowa, the research period was unfortunately only the years 1971-1991. Data for all cities were developed in 2004 by Narowski [32].

- Typical Meteorological Year from Photovoltaic Geographical Information System (TMY PVGIS) [33], containing data for many countries of the world, including Poland, with the option of selecting individual locations using Interactive tool TMY generator. For Częstochowa, datasets determined for years respectively 2005-2014, 2006-2015, 2007-2016 were received from the PVGIS database [33].

\section{Analysis of the results}

The solar radiation passing through the atmosphere is weakened and reaches the surface as direct radiation or indirect radiation - which can be diffuse or reflected [10, 34]. The solar irradiance means the density of the radiation power incident per second, per unit surface perpendicular to the direction of radiation $[10,34]$. The typical range of its variability is $100-800 \mathrm{~W} / \mathrm{m}^{2}$, although with a clear sky it has over $1000 \mathrm{~W} / \mathrm{m}^{2}[16,17]$. Due to the editorial limitations of this article, the placing of graphs showing the comparison of variations in solar irradiance in all 90 days, obtained from two series of measurements and from four TMY versions, is significantly impeded. Therefore, Fig. 1. shows only an exemplary comparison of the results obtained for representative three days selected from the examined summer period, as a small part of a very extensive material carried out in-depth analysis. The graphs show a significant set of generated peaks, indicating the occurrence of cloudiness during measurements in 2006 and in 2018. The black line, graph with the smallest amplitude, defining the course of variation of typical averaged values of solar irradiance, was determined on the basis of TMY PL for Częstochowa.

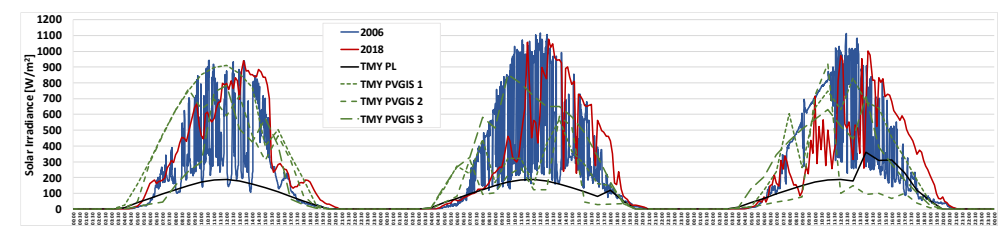

Fig. 1. An exemplary comparison of solar irradiance data obtained from two series of measurements with values from four TMY sets, for three days respectively. 
Only for these few example days, there is a clear discrepancy between TMY PL solar irradiance values and data from two measurement series, as well as TMY PVGIS sets for three different decades. A comparison of whole sets of values stored in the two rounds of measurements shows, that the sum of solar irradiance recorded throughout the summer of 2018 years were higher in relation to the same period of 2006 by $17.83 \%$. For the needs of a collective, condensed comparative presentation of the variability of solar irradiance data, Tab. 1. is provided. In order to more easily visualize the obtained measurement results, the data were grouped into sets of values for particular ranges of solar irradiance. Percentages values were determined as a reference to the number of measurement data from a given range, to the total number of measurements carried out within 90 days. The entire set was reduced by the data referring to the period of night, so their number was 86400 values. Then, the solar irradiance values relating to the summer period, taken from the four available TMY set [31, 33], were similarly developed. The largest share in both groups of measurement data have solar irradiance values in the range below $100 \mathrm{~W} / \mathrm{m}^{2}$, respectively $23.38 \%$ in 2018 and $35.95 \%$ in 2006 . Such high shares are evidence of recording solar irradiance values in the initial or last hours of the day, after sunrise and before sunset, as well as the occurrence of cloud cover and the registration of diffused radiation by measuring devices. The analogy is for data from TMY PVGIS, with the exception of TMY PL, for which the largest number of solar irradiance values is in the range $100-199.9 \mathrm{~W} / \mathrm{m}^{2}$. The analysis of data contained in the next ranges indicates that the summary results of measurements carried out in 2018 show more favourable solar conditions in Częstochowa compared to the results of measurements in 2006. In Tab. 1. the background colour highlights data from the ranges of solar irradiance values above $600 \mathrm{~W} / \mathrm{m}^{2}$, which may have real significance for obtaining energy through the use of dedicated solar energy devices such as photovoltaic cells or solar collectors. And so, in measurements from 2018, a higher share of these values is visible, constituting as much as $25.14 \%$ of the entire range of solar irradiance, while for measurements from 2006 this share was only $20.39 \%$.

Table 1. Comparison of the percentage share of data, from measurements and TMY, in particular ranges of solar irradiance.

\begin{tabular}{|c|c|c|c|c|c|c|}
\hline \multirow{4}{*}{$\begin{array}{c}\text { The range of } \\
\text { values of solar } \\
\text { irradiance } \\
{\left[\mathrm{W} / \mathrm{m}^{2}\right]}\end{array}$} & \multicolumn{6}{|c|}{ Percentage share of various values of solar irradiance in several data sets } \\
\hline & \multirow{2}{*}{\multicolumn{2}{|c|}{$\begin{array}{l}\text { Measurements in } \\
\text { the summer period }\end{array}$}} & \multicolumn{4}{|c|}{$\begin{array}{c}\text { Data for the summer period } \\
\text { in a Typical Meteorological Year ( TMY ) }\end{array}$} \\
\hline & & & \multirow{2}{*}{$\begin{array}{c}\text { TMY PL } \\
\text { 1971-1991 }\end{array}$} & \multirow{2}{*}{$\begin{array}{c}\text { PVGIS 1 } \\
\text { 2007-2016 }\end{array}$} & \multirow{2}{*}{$\begin{array}{c}\text { PVGIS 2 } \\
2006-2015\end{array}$} & \multirow{2}{*}{$\begin{array}{c}\text { PVGIS 3 } \\
\text { 2005-2014 }\end{array}$} \\
\hline & in 2018 & in 2006 & & & & \\
\hline 0 & $6.54 \%$ & $2.27 \%$ & $3.96 \%$ & $5.69 \%$ & $5.90 \%$ & $5.76 \%$ \\
\hline $0.1-99.9$ & $23.38 \%$ & $35.95 \%$ & $20.76 \%$ & $21.88 \%$ & $24.03 \%$ & $19.72 \%$ \\
\hline $100-199.9$ & $12.38 \%$ & $13.78 \%$ & $21.67 \%$ & $16.46 \%$ & $15.07 \%$ & $13.75 \%$ \\
\hline $200-299.9$ & $9.88 \%$ & $10.45 \%$ & $10.83 \%$ & $9.10 \%$ & $9.03 \%$ & $10.07 \%$ \\
\hline $300-399.9$ & $8.43 \%$ & $6.92 \%$ & $12.50 \%$ & $8.89 \%$ & $7.92 \%$ & $9.38 \%$ \\
\hline $400-499.9$ & $7.88 \%$ & $5.08 \%$ & $10.63 \%$ & $8.96 \%$ & $8.19 \%$ & $11.18 \%$ \\
\hline $500-599.9$ & $6.37 \%$ & $5.16 \%$ & $10.76 \%$ & $6.53 \%$ & $6.11 \%$ & $10.28 \%$ \\
\hline $600-699.9$ & $6.34 \%$ & $5.03 \%$ & $5.90 \%$ & $9.10 \%$ & $9.44 \%$ & $8.47 \%$ \\
\hline $700-799.9$ & $8.00 \%$ & $5.09 \%$ & $1.94 \%$ & $7.08 \%$ & $8.33 \%$ & $7.64 \%$ \\
\hline $800-899.9$ & $6.84 \%$ & $7.25 \%$ & $0.76 \%$ & $6.18 \%$ & $5.49 \%$ & $3.33 \%$ \\
\hline $900-999.9$ & $2.95 \%$ & $2.50 \%$ & $0.28 \%$ & $0.14 \%$ & $0.49 \%$ & $0.42 \%$ \\
\hline $1000-1099.9$ & $0.83 \%$ & $0.47 \%$ & - & - & - & - \\
\hline $1100-1199.9$ & $0.15 \%$ & $0.05 \%$ & - & - & - & - \\
\hline $1200-1300$ & $0.023 \%$ & $0.005 \%$ & - & - & - & - \\
\hline \multirow[t]{3}{*}{$600-1300$} & $25.14 \%$ & $20.39 \%$ & $8.89 \%$ & $22.50 \%$ & $23.75 \%$ & $19.86 \%$ \\
\hline & \multicolumn{6}{|c|}{ Maximum of solar irradiance $\left[\mathrm{W} / \mathrm{m}^{2}\right]$} \\
\hline & 1227.0 & 1259.4 & 969.9 & 911.0 & 926.0 & 924.0 \\
\hline
\end{tabular}


Data with values above $1000 \mathrm{~W} / \mathrm{m}^{2}$ are readings from 870 and 450 measurements made within 90 days, respectively. It means, that they are not incidental, but realistically repeatable, higher than typical values occurring in this region. The maximum measured values of the incoming solar irradiance were accordingly $1227.0 \mathrm{~W} / \mathrm{m}^{2}$ and $1259.4 \mathrm{~W} / \mathrm{m}^{2}$. In contrast, the maximum values of solar radiation contained in the four TMY sets do not exceed $1000 \mathrm{~W} / \mathrm{m}^{2}$, due to the fact that the specificity of creating TMY does not take into account extreme values, but only averaged. Despite this, the share of values above $600 \mathrm{~W} / \mathrm{m}^{2}$ is a much higher percentage in all TMY PVGIS data groups, $22.50 \%, 23.75 \%$ and $19.86 \%$, respectively, compared to only $8.89 \%$ from TMY PL. Three sets defining a Typical Meteorological Year in PVGIS resources, determined from averaged data for the decades 2007-2016, 2006-2015, 2005-2014, contain significantly higher values of solar irradiance, which are more similar to the ones, confirmed in measurements carried out in Częstochowa. This proves successive inclusion in PVGIS databases [33], generated by specialized meteorological research units, current deviations of the values of weather factors and locally occurring climate changes, which unfortunately is not included in the TMY PL collection covering the years 1971-1991 for Częstochowa [31]. It was found that the actual measurements carried out are more compatible with TMY PVGIS data, as opposed to TMY PL, although Typical Meteorological Years mainly contain average values. Until the late 1980s, there was a noticeable decrease in the amount of solar radiation received on the Earth's surface, which illustrates global dimming tendencies. In contrast, in recent decades a shift towards brightening has been visible [12, 35, 36]. So, radiation data from the period 1971-1991 are not representative for the years after 2000. The presented analysis states the diversity of data in particular periods, as well as confirms the need to develop new TMY databases for particular locations. In the analysis of summer local solar conditions, a different factor characterizing solar radiation, called sunshine duration, describing the number of hours reaching direct solar radiation in a day, month or year, respectively, was also taken into account $[34,38]$. The average value of annual sunshine duration in Poland is 1650 hours [16]. For Częstochowa, the average annual sunshine duration, according to the WO Meteorological Services [37], determined in the period 2006-2018 is $1713.0 \mathrm{~h}$ and in 2018 the value reached even $1961.9 \mathrm{~h}$ of which $733.6 \mathrm{~h}$ was for the summer season, as $37.4 \%$ of the whole year. For comparison, in 2006 the summer sunshine duration was $700.1 \mathrm{~h}$ which is $41.5 \%$. Despite the fact, that the total sunshine duration values in both summer periods are similar, it is worth noticing that there are significant differences for July and August in the year 2006. The exact values of sunshine duration for individual months and the entire summer season in Tab. 2.

Table 2. Comparison of the annual, monthly and summer sunshine duration lown study based on data from WO [37].

\begin{tabular}{|c|c|c|c|c|c|c|c|c|c|}
\hline & \multicolumn{10}{|c|}{ Sunshine duration [h] in: } \\
\cline { 2 - 10 } & Year & \multicolumn{2}{|c|}{ June } & \multicolumn{2}{|c|}{ July } & \multicolumn{2}{c|}{ August } & \multicolumn{2}{|c|}{ Summer } \\
\cline { 2 - 10 } & $\mathrm{h}$ & $\mathrm{h}$ & $\begin{array}{c}\% \text { of } \\
\text { year }\end{array}$ & $\mathrm{h}$ & $\begin{array}{c}\% \text { of } \\
\text { year }\end{array}$ & $\mathrm{h}$ & $\begin{array}{c}\% \text { of } \\
\text { year }\end{array}$ & $\mathrm{h}$ & $\begin{array}{c}\% \text { of } \\
\text { year }\end{array}$ \\
\hline $\mathbf{2 0 1 8}$ & $\mathbf{1 9 6 1 . 9}$ & 211.1 & 10.8 & 258.1 & 13.2 & 264.4 & 13.5 & $\mathbf{7 3 3 . 6}$ & $\mathbf{3 7 . 4 \%}$ \\
\hline $\mathbf{2 0 0 6}$ & $\mathbf{1 6 8 7 . 8}$ & 237.7 & 14.1 & 309.8 & 18.4 & 152.6 & 9.1 & $\mathbf{7 0 0 . 1}$ & $\mathbf{4 1 . 5 \%}$ \\
\hline
\end{tabular}

Additionally, the anomalies of monthly sunshine duration documented in the IMGW-PIB resources [22], determined in relation to the data from 1971-2000, for the analysed location and the summer period in 2018, are included in the range of 40-100 h, and the annual sum of sunshine duration is currently higher than the long-term average by about 10-25\% depending on the year $[22,38]$. However, with regard to the possibility of energetic use of the solar radiation potential, it should be taken into account, that high sunshine duration does not translate unequivocally into an increase the intensity of solar radiation, because also 
depends on: the specificity of the place, the angle of incidence of rays, local climatic factors, and to a large extent, the quality of the atmospheric air. During the last 40 years, the warming of the climate of the Silesia Voivodeship, and the Częstochowa region, has been observed by IMGW [22]. The analyses carried out in the "Plan for adaptation to climate change in the city of Częstochowa up to 2030" [39] show, that local, major climate threats will be in the future: increase in the number of summer hot days and the maximum air temperature, which is caused by the impact of solar energy. The area of Częstochowa is shaped by natural factors and largely anthropogenic factors and intense urbanization. Large population and industrial activity are characterized by the specificity of the climate burdened with the influence of air pollution, which significantly limit the transparency of the atmosphere. Air pollution is caused by anthropogenic emissions from surface sources (municipal), point sources (professional power industry, technological processes) and linear emissions (transport) [16, 17, 39-41]. Air quality may also change as a result of the inflow of pollutants from adjacent areas. The condition of atmospheric air quality is especially thoroughly analysed in the winter, which is characterized by the occurrence of the so-called heating season. However, also for summer, frequent exceedances of the permissible values, e.g. particulate matter $\mathrm{PM}_{10}$ and other factors are recorded. The reason for this is the proximity of roads with high traffic intensity, secondary emissions of dust pollution from discovered surfaces, or adverse meteorological conditions, such as low wind speed, causing very slow spread of local emissions [41]. Particulate matters in the atmosphere are small impurities with different composition, density, properties, and can cause significant disturbances in the solar radiation balance [40]. Local air pollution, from transport or production processes, can reduce the solar radiation in the summer even by up to $30 \%[16,40]$. An exemplary comparison of $\mathrm{PM}_{10}$ particulate matters concentrations occurring during the analysed three summer months of 2018 in Częstochowa, in relation to the daily limit value, is shown in Fig. 2. Hourly data for PM10 concentrations was obtained from the resources of the Chief Inspectorate for Environmental Protection GIOŚ [42], for the measuring station PL0526A, Częstochowa AK/Jana Pawła II (latitude 50.8177 and longitude 19.1174), located $1 \mathrm{~km}$ from the place of measurements of solar conditions. The data in the GIOŚ databases [20] are usually averaged from measurements from the whole day to one daily value and compared with the $\mathrm{PM}_{10}$ limit of $50 \mu \mathrm{g} / \mathrm{m}^{3}$. Often, as a result of such an interpretation, the overruns occurring at individual hours are eliminated. However, during the discussed 90 days of the summer of 2018, episodes of exceeding the admissible value for $\mathrm{PM}_{10}$ in Częstochowa were also noticed, Fig. 2.

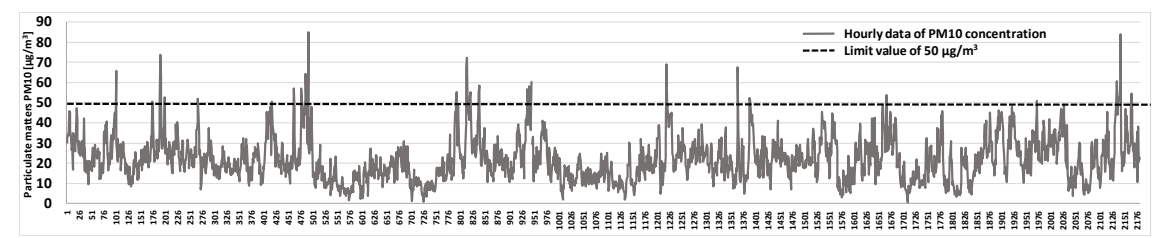

Fig. 2. Particulate matters $\mathrm{PM}_{10}$ concentrations, during the three summer months, in relation to the limit value of $50 \mu \mathrm{g} / \mathrm{m}^{3} / \mathrm{own}$ study based on data from [42].

The propagation of dust pollution in atmospheric air can significantly destabilize solar conditions and limit the availability of solar radiation, and thus the possibility of obtaining energy. It should also be remembered, that dust particles deposited directly on the measuring equipment may cause disruptions in the results, as well as accumulated on devices obtaining solar energy, may reduce their efficiency. 


\section{Conclusions}

The changes of local, summer climate conditions, observed in recent decades, introduce the need to insightful analysis and update the values of parameters included in the Typical Meteorological Year TMY PL, and especially data sets determining the solar irradiance. Unfortunately, not all meteorological stations are equipped with actinometrical measurement devices as standard, hence the issue of the lack of data availability determining local solar conditions needed to determine a Typical Meteorological Year, is a common problem in the world and does not apply only to Poland or locally Częstochowa. The values of solar irradiance placed in TMY databases for many countries, unfortunately, come mainly from modeling based on other meteorological parameters, hence they often differ significantly from the actual conditions. This is confirmed by the measurements of solar parameters performed in a specific location, which additionally take into account the impact of weather anomalies, air quality or other individual factors shaping the local climate. For example, also in the summer there may be a problem of the negative impact of atmospheric air pollution, the effect of which is limiting the potential local solar energy availability. Presented in the article comparison of solar irradiance in the summer for Czestochowa, obtained from two series of measurements, with data from TMY PL, as well as from three TMY PVGIS databases, showed that data describing summer solar conditions in the Polish Typical Meteorological Year are significantly understated. In addition, noteworthy, that the climate factors used for the creation of TMY PL for Częstochowa, monitored by IMGW-PIB, unfortunately came from observations conducted in 1971-1991, and the values of solar irradiance were largely modeled and interpolated, which suggests their out of date. Therefore, the creation of local databases of solar conditions is a very useful project, which requires, however, long-term gathering of material to determine the overall picture of variability of parameters. The measurement results discussed in this article are a part of the successively created database, which, after collecting sufficiently large material, can be a useful set of solar irradiance data for Częstochowa. Urgent updating of databases of TMY for the area of Poland are indispensable for the correct determination of energy performance of buildings as well as for determining local possibilities of solar energy obtaining. In addition, a significant amount of high solar irradiance, occurring during the summer, suggests the need to create, an auxiliary data set, as was done in other countries, that takes into account just this highest values, for example Near-extreme Summer Reference Year [27]. Such a set would be useful in Polish conditions, not only to determine the potential opportunities of photothermal or photovoltaic conversion, but also to eliminate the problem of building overheating, as well as for the selection of modern solar systems used for powering air-conditioning devices and to meet the energy demand for cooling. Carried out analysis confirmed, that the potential of solar energy in Częstochowa is becoming more and more favourable, and it is worth to interest individual customers also to solar energy, especially, that for investments related to solar collectors and photovoltaic panels.

The material was prepared as part of statutory research of the Czestochowa University of Technology BS/PB-401-301/18.

\section{References}

1. R. Rawlings, Capturing solar energy (CIBSE Know. Ser. London, 2009)

2. W. Weiss, M. Spörk-Dür, Solar Heat Worldwide (IEA, 2018)

3. J. Paska, Wytwarzanie rozproszone energii elektrycznej i ciepła (Ofic. Wyd. Pol. Warszawskiej, Warszawa, 2010) 
4. M. Thirugnanasambandam, S. Iniyan, R. Goic, Ren. \& Sust. En. Rev. 14, 312-322 (2010)

5. B. Igliński, M. Cichosz, W. Kujawski, M. Plaskacz-Dziuba, R. Buczkowski, Ren.\& Sust. En. Rev. 58, 862-870 (2016)

6. C. Coskun, Z. Oktay, I. Dincer, Ener. 36, 1319-1323 (2011)

7. H. K. Elminir, Meteorol. Atmos. Phys. 96, 245-256, 257-264 (2007)

8. Z. Caputa, Pr. Geograf. 147, 81-97 (2016)

9. K. Bryś, Inż. Ekol. 44, 53-61 (2015)

10. M. Sengupta, A. Habte, S. Kurtz, A. Dobos, IEA, NREL/TP-5D00-63112 (2015)

11. P. Narowski, COW 12, 45, 479-485 (2014)

12. M. Kejna, J. Uscka-Kowalkowska, Bul. of Geogr. 15, 27-40 (2018)

13. M. Gazela, E. Mathioulakis, Sol. En. 70, 339-348 (2001)

14. T. Lhendup, S.Lhundup, En. for Sust. Dev. 11, 5-10 (2007)

15. E. Żmudzka, Acta Agr. 13, 2, 555-568 (2009)

16. E. Wołoszyn, Meteorologia i klimatologia w zarysie (Wyd. Pol. Gd., Gdańsk, 2009)

17. K. Kożuchowski, Meteorologia i klimatologia (Wyd. Nauk. PWN, Warszawa, 2006)

18. A. Arguez, R. S. Vose, Bul. of the Amer. Met. Soc. 92, 699-704 (2011)

19. B. Bogdańska, J. Podogrocki, Mat. bad. IMGW, Meteo. 30, 1-43 (2000)

20. K. Bryś, T. Bryś, Pam. Puł. 144, 13-34 (2007)

21. K. Bryś, T. Bryś, Met. Hydr. and Wat. Manag. 7, 1-13 (2019)

22. IMGW-PIB, Institute of Meteorology and Water Management, http://www.imgw.pl

23. EN ISO 15927-4, European technical standard

24. A. Ebrahimpour, M. Maerefat, En. Conv. \& Man. 51, 410-417 (2010)

25. J. N. Hacker, S. E. Belcher, A. White, Char. Inst. Build. Serv. Eng., CIBSE TM49 (2014)

26. M. Herrera, S. Natarajan, D. A Coley, Build. Serv. Eng. Res. \& Tech. (2017)

27. M. F. Jentsch, M. E. Eames, G. J. Levermore, Build. Serv. Eng. Res. \& Tech. (2015)

28. CIBSE, Weather Data Sets, https://www.cibse.org/weatherdata

29. WMO, Guide to Meteorological Instruments and Methods of Observation, 8 (2012)

30. T\&D, https://www.timeanddate.com/sun/poland/czestochowa

31. MIiR, Ministry of Investment and Development, https://www.gov.pl/web/inwestycjerozwoj/dane-do-obliczen-energetycznych-budynkow

32. P. Narowski, Ryn. Instal. 10, 52-57 (2008)

33. PVGIS, Photovoltaic Geographical Information System, Joint Research Centre, http://re.jrc.ec.europa.eu/pvgis.html

34. J. Kleissl, Solar Energy Forecasting and Resource Assessment (Elsev. Sc. \& Tech., Acad. Pr., 2013)

35. M. Wild, J. Geophys. Res. 114, (2009)

36. C. W. Stjern, J. E. Kristj'ansson, A. W. Hansen, Int. J. Climatol. 29, 643-653 (2009)

37. WO, WeatherOnline Ltd. - Meteorological Services, http://www.weatheronline.pl

38. C. Koźmiński, B. Michalska, Acta Agr. 3, 2, 291-305 (2004) 
39. MŚ, Plan adaptacji do zmian klimatu miasta Częstochowy do roku 2030, Ministry of the Environment (2018), http://44mpa.pl/czestochowa

40. K. Juda-Rezler, B. Toczko (red.), Pyty drobne $w$ atmosferze (Bibl. Monitor. Środ., Warszawa, 2016)

41. IOŚ, Stan środowiska w województwie śląskim (Bibl. Monitor. Środ., Katowice, 2018)

42. GIOŚ, Bank danych pomiarowych, http://powietrze.gios.gov.pl/pjp/archives 